\section{Czech Economic Review}

Acta Universitatis Carolinae Oeconomica

\author{
PETR HEDBÁVNÝ \\ ONDŘEJ SCHNEIDER \\ JAN ZÁPAL ${ }^{*}$
}

\title{
A FISCAL RULE THAT HAS TEETH: \\ A SUGGESTION FOR A 'FISCAL SUSTAINABILITY COUNCIL' UNDERPINNED BY THE FINANCIAL MARKETS
}

\begin{abstract}
:
In this paper, we set out to examine an efficient fiscal-policy framework for a monetary union. We illustrate that fiscal policy's bias toward budget deficit only temporarily ceased at the end of the $20^{\text {th }}$ century as European countries endeavored to qualify for euro-zone membership, which compelled strict limits on budgetary deficits. We then explore which mechanisms might instill a sense of fiscal disciple in governments. We find that most mechanisms suffer from the incentive-incompatible setup whereby governments restrict their own fiscal-policy freedom. We argue that even multilateral fiscal rules, such as the EU's Stability and Growth Pact, suffer from the same endogeneity flaw. Consequently, we argue that a fiscal rule must incorporate an external authority that would impartially assess fiscal-policy developments. Using U.S. debt and bond-market data at the state level, we show that financial markets represent a good candidate as, vis-à-vis the American states, they do differentiate state debt according to the level of debt. We thus argue for a fiscal institution - what we call the Fiscal Sustainability Councilthat would actively bring financial markets into the fiscal-policy process, and we explain the technique whereby this could be effected.
\end{abstract}

Keywords: fiscal policy, European Union, sustainability

JEL Classification: E6, H6, H87

Acknowledgements: This research has been supported by a grant from the CERGE-EI Foundation under a program No. GRCIV-020. We have also benefited from a grant No. 402/2004, and from discussions with Martin Gregor and Vladimír Bezděk. An earlier version of this paper was published as the CESifo Working Paper Series, No.1499 in July 2005. The responsibility for all omissions and errors is, however, solely of the authors.

I used to think if there were re-incarnation I wanted to come back as the president or the pope... But now I want to come back as the bond market. You can intimidate everybody.

James Carville

Former chief strategist to U.S. President Bill Clinton

\section{Introduction}

Fiscal policy - the levels of government taxes and expenditures - remains the most intriguing economic policy issue early in the 21 st century. While the 1990 s saw a considerable consolidation of fiscal positions in most countries, the new century has been marked by rapidly

\footnotetext{
* Institute of Economic Studies, Charles University Prague, Opletalova 26, Prague 1, 110 00, Czech
} Republic.E-mails: hedbavny@fsv.cuni.cz, schneider@fsv.cuni.cz, zapal@mbox.vol.cz 
deteriorating fiscal positions in most developed countries. This development is accompanied by the flouting of fiscal rules by many European governments, chiefly the multilateral stability and growth pact (SGP), as enacted in 1997 by the European Union (EU) toward European Monetary Union (EMU).

We focus on fiscal policy mainly in two regards. First, the overall fiscal policy of many countries appears to be unsustainable at present. Radical policy change seems unavoidable as most industrialized-country populations undergo profound demographic aging, which will require ever-higher levels of public spending on health care, pensions, and other social-security programs. Second, fiscal policy has a central role in multilateral monetary unions, wherein governments relinquish their monetary-policy capacity. The resulting increased need for fiscal-policy flexibility is, however, largely constrained by the apparent necessity to coordinate fiscal policies in consort.

In the European context, many economists have sharply criticized the makeup, logic, and workings of the SGP within the EMU. Many have argued that it is backward-looking; that it might constrain fiscal policy when it is most needed as independent monetary policy of member states was conveyed to European Central Bank; that the union-wide reference values (i.e., the constraints) of 3 percent of public deficit and 60 percent of public debt (respective to GDP) are, in effect, arbitrary that the pact is arbitrarily enforced; that it will cause deficit-spending governments in the face of the pact's penalty-imposing "excessive deficit procedure," to sacrifice investment spending; that its one-size-fits-all nature is not suitable for Europe, which is anything but an optimum common-currency area; and, most lately, that it is totally inappropriate for new (and anticipated) EU member states.

In this paper we analyze the reasons, consequences, and potential rules concerning the limitation of excessive fiscal deficits in the context of monetary union. We discuss recent fiscal-policy developments in the EU. We argue that the fiscal worsening that has transpired over 2002-2004 has deeper roots than just a cyclical development. We analyze attempts to restrain fiscal-policy arbitrariness through a fiscal rule. We show that many such attempts suffer from low credibility and from incentive incompatibility. In that regard, the all-but-formal demise of the SGP is certainly a point in our case.

We then look for alternative ways how to safeguard and support sound fiscal policy. We argue that an external authority, one that would regularly assess fiscal-policy developments, is needed. We argue that financial markets could play an active role in a new fiscal setup. Using a large panel data from the United States, we show that, there, fiscally more responsible states achieve lower interest rates when they sell their debt on financial markets.

Finally, we attempt to formulate a proposal for the introduction of a new, European fiscal authority - a Fiscal Sustainability Council (FSC) - that would have the authority to prescribe annual deficits (or surpluses) to individual countries and that would report to the European Parliament, and perhaps more importantly, that would inform and guide financial markets as to which country's fiscal policies are sustainable and which are not. In order to be most effective, the Council would be responsible for rolling over a substantial amount of the government bonds of each member country. By doing so, the Council would be able to guide markets more precisely, as it would be re-selling government bonds on an annual basis. It would, thus, be in regular contact with financial markets and would be able to communicate to them its assessment of various national fiscal policies.

We believe that our suggestion would allow a beneficial separation of the distributive (political) and the stabilizing (technocratic) roles of fiscal policy. It would also cultivate relations with financial markets and their comprehension of fiscal-policy sustainability. By doing so, the FSC would better facilitate the application of the EU's common currency and would also prevent future fiscal crises.

The paper is organized as follows: First, we review the arguments and empirical support for the hypothesis of a deficit bias in government policies. In the second part, we analyze existing fiscal regimes and reveal their inadequacies. The third part explains why financial 
markets may be useful toward establishing a fiscal rule, and the fourth part supports our concept with an empirical analysis of market efficiency in the U.S. bond market. Finally, we propose a modified fiscal-institution framework for the European Union, relying on an independent authority, the FSC, that would set appropriate deficit limits for EU countries using forward-looking parameters aimed at securing sustainable levels of explicit and implicit governmental debt. We also discuss the advantages and the possible pitfalls of such a proposal.

\section{Are Governments Biased toward Deficit Spending?}

The concept of persistently increasing government spending and an expansive public sector within the democratic process was first proposed by Buchanan and Wagner (1977). They identified a so called fiscal-illusion effect, which stems from the fact that during the budget process politicians do not fully internalize the costs associated with rising revenues needed to finance public activities. Therefore, politicians constantly overestimate the benefits associated with public activities and persistently undervalue the costs associated with increasing taxes. This, possibly non-intentional, aspect can be exacerbated by the deliberate use of public funds for private benefits, as shown in Becker (1983) or by budget-maximizing effort of public bureaucrats, as analyzed in Niskanen (1968).

Deficit bias, stemming from the increased need for public funds of a spending-biased government, stems from two factors. One is that current voters evaluate costs associated with increased taxes differently from the costs associated with higher government deficits. While increased taxes directly lower taxpayers' disposable incomes, government deficits are associated with costs such as higher inflation or higher public debt risk premium in other words, while the costs of taxes are real and immediate, the costs associated with deficits are notional and deferred (to when the responsible government is no longer in office).

The second factor is that during the budget process the interests of future taxpayers are not properly represented. In fact, the future (largely unborn) generation cannot possibly have a voice when it comes to decisions of how to finance, current spending. Therefore, politicians defer many costs to the future, which creates a deficit bias.

This story is clearly consistent with the expanding public sector, rising debt levels, and the rising deficits of most developed countries in the second half of the twentieth century. While the public sector grew steadily, as Wyplosz (2005) notes, taxes tottered behind, which meant rising deficits and public debts. The contemporary European fiscal position illustrates this. Indeed, three of the fifteen "old" EU members (i.e., pre-2004 members) had debts in excess of 100 percent of their respective GDPs in 2003 (Italy, Belgium, and Greece). ${ }^{1}$ Indeed, as our analysis in the next chapter shows, many European governments returned to aggressive deficit spending immediately after fulfilling the entry criteria for the EMU. Such fiscal-policy development illustrates the need for an external anchor.

\section{The Fiscal Positions of Old and New EU Members}

The new millennium has, so far, seen a steady worsening of the fiscal stance of most developed countries. EMU members' recently found sense of fiscal restraint dissipated following euro-zone entry, and euro-zone ledgers are now awash in red ink. The unweighted average of the deficit-to-GDP ratio of the old EU members is highly illustrative. From -5.1 percent of GDP in 1995, the average deficit declined to -0.7 percent of GDP in 1999, the year of the final fixing of exchange rates vis-à-vis the still non-cash euro, and eventually reached 1.0 percent of GDP in $2000 .^{2}$ The average deficit ratio subsequently declined in the face of unfavorable

\footnotetext{
${ }^{1}$ In case of Greece, the debt was later re-scaled (i.e. increased) by 14 percent of GDP in 2004 when the government found the fiscal books of its predecessor wanting..

${ }^{2}$ However, as Briotti (2004) notes, fiscal cuts that took place prior to the euro's introduction consisted of one-off, temporary measures, were based on increases in revenues, and put little emphasis on primary expenditure restraint.
} 
economic development, to -2.6 percent of GDP in 2003, and is expected to remain around this value for the next two years. ${ }^{3}$ Truly, the envisaged position of "close to [a] budget balance or in surplus" is yet to materialize.

Transition-economy countries, on the other hand, have always been a little different. They began the 1990s with high levels of public spending, highly distortive and arbitrary tax systems, and radical economic reconfiguration. The fiscal pressures that resulted from this mix were enormous and most transition countries, sooner or later, experienced severe fiscal problems. As a group, however, the Central and Eastern European (CEE) countries managed to cut public debt from more than 100 percent of GDP in 1992 to less than 60 percent in 2002. The reasons for this development are numerous. Governments of CEE countries received considerable amount of funds from large-scale asset privatization; "non-standard" accounting practices and vaguely defined data-gathering methodology might also have improved the picture; and positive development might have been facilitated by special events, such as, for example, some generous debt underwriting in the case of Poland, and fiscal consolidation in Russia powered by high oil prices.

Recent trends among transition countries are more worrisome, however. The ten countries that joined the European Union in May 2004 - Cyprus, Czech Republic, Estonia, Hungary, Latvia, Lithuania, Malta, Poland, Slovakia, and Slovenia - recorded public deficits, on average, of -3.2 percent of GDP in 2000 and of -5.7 percent in 2003. Deficits are expected to decrease (the European Commission's forecast is of -4.2 percent of GDP in 2005), however, as a result of the expected effort of most of to fulfill the Maastricht criteria toward EMU entry. ${ }^{4}$

Needles to say, there are wide disparities among the new EU member states. Some of the most advanced countries in this group have seen deficit-to-GDP ratios as high as -12.3 percent (Slovakia in 2000), -12.9 percent (Czech Republic in 2003), and -9.3 percent (Hungary in 2002). On the other hand, there is a group of countries - namely Slovenia, Latvia, and Lithuania - with only moderate deficits (around -1.8 percent of GDP on average in 2003); and then there is Estonia, which has experienced budget surpluses since 2001. These countries also display lower debt-to-GDP levels. Estonia had a 5.8 percent ratio in 2003 , and the rest of the more fiscally responsible new member states did not owe more than 28 percent of GDP in 2003 . Nevertheless, seven out of ten new member countries currently breach the SGP rules, and the European Commission has launched the excessive deficit procedure against them.

The disparity among the new EU members, coupled with the disparity of the original old member states, might require more flexible interpretation fiscal rules, as already advocated by the European Commission under tutelage from some European governments. Nevertheless, this increased flexibility comes at the price of lower transparency as discretionary decisions will have to be made concerning whether a country is in violation of the limits on deficit or not. Therefore, the traditional trade-off between rules and discretion, flexibility and credibility in the working of the SGP is extended by the accession of the ten new countries to European Union.

\section{Rationale for Fiscal Rules}

Given the apparent failure of fiscal policy to maintain fiscal stability, we propose as an alternative a rule-based system whereby fiscal policy would be subject to an external limit. While the variable at which this limit is imposed might vary (annual deficit, total debt, cyclically adjusted deficit, etc.) the rule would inevitably limit the freedom of policy makers and limit politicians' reign. This makes fiscal rules controversial. What government would like to be subject to an external rule? As the row about Germany's and France's breach of the SGP vividly illustrates, politicians scorn any external authority that can impose jurisdiction over their tendency to set budget deficits according to their (rather short-term) goals.

\footnotetext{
${ }^{3}$ Public Finances in EMU 2003, European Economy.

${ }^{4}$ The appendix provides data on the deficit- and debt-to-GDP ratios of the ten new EU member countries, the original EU members, and the United States and Japan.
} 
And still, were not central governments similarly beleaguered some twenty years ago, when monetary policy was taken from them and vested in independent central banks? As politicians, especially in Europe, were not trusted to run prudent monetary policy, the power to set interest rates and intervene in currency markets was widely transferred to a non-elected, technocratic institution, with some oversight from parliaments. This transfer has proved to be successful, as independent central banks have run monetary policy in a less myopic and more sustainable manner than did politicians.

Why should fiscal policy be any different? Certainly, fiscal decisions lie at the heart of many government policies. ${ }^{5}$ Politicians often win or lose elections on their pledges to increase spending for particular programs or to introduce tax preferences. Inefficient as it often is, this political process should not be eliminated. Government will always have the ultimate authority to set taxes and spend revenues. However, this authority need not be limitless. As we show below, it may be perfectly compatible with democracy for governments to accept overall limits on spending and set its structure according to political preference. Or governments may be told only what a deficit (or surplus) must be and then decide on the amounts to rise through taxes or to spend on various expenditure programs. Such a mechanism would let governments redistribute such as they see fit, and would allow them to normally finance expenditures programs, such as defense, health, etc. It would, however, expose governments to hard budget constraints.

Indeed, even now many countries pursue different fiscal institutional arrangements that limit governments' flexibility. ${ }^{6}$ The United States uses nominal caps on discretionary spending, while Britain uses the "golden rule" (borrowing only to finance investment). Perhaps most famously, the European Union has adopted the SGP, which places limits on national budget deficits and debts and assigns penalties to countries that exceed those limits.

The main objective of such arrangements is to reinforce the credibility and predictability of macroeconomic policies. In other words, fiscal rules are usually aimed at mitigating a government's tendency to abandon previous policy commitments. Thus fiscal rules are particularly helpful if a government is not able to persuade economic actors that it will conduct a prudent fiscal policy.

Fiscal rules are sometimes criticized for being redundant, for representing an unnecessary bureaucratic obstacle, or for being conducive to misuse via "creative accounting." However, even as an imperfect tool, fiscal rules can play a positive role. They introduce a long-term horizon to government's often-shortsighted decision making. Fiscal rules also provide a more transparent information to financial markets, the ultimate source of fiscal discipline for governments, as strict transparency requirements are identified as a common denominator of efficient rules. ${ }^{7}$ Without such a guide, financial markets react to a change in fundamentals with a considerable time lag and they impose high costs (sudden capital outflow, a high-risk premium) on the government that departs from prudent fiscal policy.

In order to guide fiscal policy successfully, fiscal rules should be forward-oriented and should incorporate increasing pension entitlements stemming from aging populations. ${ }^{8}$ Fiscal rules should also encompass various quasi-fiscal transfers and programs that are used to mask the true size and effects of fiscal policy. Some authors also argue that fiscal-policy rules should take into account the uncertain character of fiscal revenues and expenditures and use more sophisticated financial methods to estimate the "value at risk" of a fiscal policy. ${ }^{9}$

\footnotetext{
${ }^{5}$ This part draws on (Hedbávný, Schneider, 2003).

${ }^{6}$ In this paper, a fiscal-policy rule means a permanent constraint on fiscal policy, expressed in terms of an indicator of overall fiscal performance, such as government deficit, borrowing, or debt (i.e. we follow the definition of Kopits and Symansky [1998]). A rule is often expressed as a numerical target for a public budget deficit or debt as a share in GDP.

${ }^{7}$ See (Craig, Kopits, 1998) on transparency in fiscal policy.

${ }^{8}$ For more on the issue of implicit pension debt, see (Schneider, 1999).

${ }^{9}$ See (Barnhill, Kopits, 2003)
} 


\section{The Stability and Growth Pact and Its Failures}

The EU has implemented an ambitious system of fiscal rules that is intended to prevent excessive deficits (and, eventually, debts) among euro-zone countries. The system - the aforementioned stability and growth pact - goes much further than the EU's 1992 Maastricht Treaty, which created the monetary union and set five basic conditions for membership. Two of these conditions constrained the fiscal policy of prospective EMU members as members are forbidden to run deficits greater than 3 percent of GDP, and debt should be maintained below 60 percent of GDP. As the EMU was established, the debt condition - manifestly unachievable for profligate borrowers such as Italy, Belgium or Greece - was scaled down. Instead, the SGP concentrated on annual deficits. Three new aspects of fiscal policy were mandated by the SGP:

- EMU members are to endeavor to achieve a balanced or a surplus budget in order that they have enough leeway in the event of cyclical downturns; objectives:

- EMU member countries are to submit annual programs specifying medium-term budgetary

- if an EMU member country runs a budget deficit exceeding 3 percent of GDP, pena-lization will follow; a country can be exempted from the obligation to pay a deposit (which can become a fine) if it suffers from annual GDP decline of more than 0.75 percent, and is exempted from the obligation if a cyclical downturn of more than 2 percent occurs.

While these three conditions are not unreasonable, they have failed to prevent lax fiscal policies in the EMU. In fact, member countries' fiscal deficits quickly deteriorated when the euro-zone entered a cyclical slowdown after 2000. The SGP was formally suspended in 2003 after Germany and France made a compromise with eurozone finance ministers not to fine them for breaching Maastricht criteria on budget deficit for three years in a row. ${ }^{10}$ In this chapter, we concentrate on three aspects of the SGP that make the pact unlikely for a fiscal-rule application. We will namely argue that: (i) SGP rules complicate the free operation of automatic stabilizers, (ii) they do not take into account the unfunded liabilities of governmental programs, and (iii) they do not lead governments to behave in a forward-looking manner.

\subsection{SGP Rules Complicate the Free Operation of Automatic Stabilizers}

European governments tended to conduct pro-cyclical fiscal policies in the years before EMU membership (Buti, Franco, Ongena, 1997), and the deficit bias did not disappear after 1999 as the SGP is not supported by an efficient enforcement mechanism. Consequently, the deficit rule (if enforced) becomes a binding constraint for the operation of automatic stabilizers. As predicted by Eichengreen and Wyplosz (1998, p. 69), "the Stability Pact will grow more binding [...] increasing the volatility of output, further depressing growth, and making the provisions of the pact even more binding than before. Through the operation of this vicious spiral, Europe could be condemned to a low-level equilibrium trap."

Recurrent fiscal tightening in low-growth periods can have adverse effects on long-term growth prospects. It can lead to under-investment in both human capital and physical capital and a failure to maintain it. The use of automatic stabilizers requires some caution. Automatic stabilizers should operate symmetrically over the business cycle rather than being undermined by discretionary expenditures in boom periods (van den Noord, 2002).

\subsection{The SGP Rules do Not Take into Account Unfunded Liabilities}

Neither the SGP rules nor their pre-EMU counterpart, the Maastricht criteria, take into account the unfunded liabilities of governmental programs. ${ }^{11}$ They tackle explicit deficits and debts only. Explicit government debt can be a good approximation of total governmental liability. However, as politicians replace budgetary outlays with promises, with fulfillment costs to be borne by future

\footnotetext{
${ }^{10}$ Nevertheless, the SGP has been included in the European Union's draft constitution, though negotiations on modifying it continue.

${ }^{11}$ Indeed, the Eurostat decision from 2004 to take into account only increases in "visible" deficits, which often result from structural reforms in the pension systems, but to ignore cuts in "invisible" (implicit) debts achieved by the very same reforms shows that the current fiscal framework is reform incompatible.
} 
taxpayers, the explicit debts provide only partial picture. Indeed, the net present value of the implicit debt of public pension systems (based on unchanged policies; for details, see (ABN Amro, 2003)) ranges from 14 percent of GDP for the UK to 698 percent of GDP for Greece (ABN Amro, 2003). ${ }^{12}$

TABLE 1 Public Pension Debt (\% of GDP)

(net present value of the public pensions debt to 2050, based on unchanged policies)

\begin{tabular}{|l|l|l|r|}
\hline Austria & 223 & Italy & 230 \\
Belgium & 296 & Luxembourg & 199 \\
Denmark & 264 & Netherlands & 85 \\
Finland & 327 & Portugal & 327 \\
France & 332 & Spain & 665 \\
Germany & 188 & Sweden & 201 \\
Greece & 698 & UK & 14 \\
Ireland & 150 & Czech Republic & $200-250^{*}$ \\
\hline
\end{tabular}

Note: * Estimate (Schneider, 1999)

Source: ABN AMRO, "Desire to retire: The European Pension Problem," report, 2003.

Moreover, the EMU rules do not account for off-budget liabilities, which have encouraged governmental manipulation with budgetary figures. We believe that the low transparency of governmental fiscal policy and the replacement of budgetary outlays with the off-budgetary ones will not support European growth prospects, either. Though the risk premiums on high-debt EMU countries are low (Portes, 2003), a publication of the ratings agency Standard and Poor's (2002) clearly shows that implicit pension debt is likely to heavily influence the credit ratings (and subsequently, the borrowing costs) of European countries. ${ }^{13}$

\subsection{EMU Rules Are Backward-Looking}

EMU rules concentrate on short- and medium-term targets. They thus divert the attention and effort of politicians away from not only much needed reform of the labor market (Eichengreen, Wyplosz, 1998), but also away from pension reform. The situation is further worsened by the non-enforcement of the medium balance rule in the early years of EMU. Beetsma and Debrun (2003) show, in a simple model framework, that EMU rules discourage structural reform. In their words, EMU rules are "sacrificing future growth for present stability".

The European Commission modified its stance on SGP in 2002 in two ways. First, it switched to cyclically adjusted budget deficits as the key variable used to assess the soundness of the fiscal stance of individual countries. This should ease pressure on those EMU members that suffer from prolonged stagnation. Second, the Commission signaled that countries which progress substantially in structural reforms will be treated "softer". While most economists agree with the Commission's stance, it is very difficult to measure a variable like an "effort to conduct structural reform."

The Commission suggested, in a summer 2004 communication, that the SGP should be maintained, but significantly revised. Namely, it advocated a shift of focus from annual deficits to "debt sustainability." It suggested a return to the debt criterion that was originally a part of

\footnotetext{
${ }^{12}$ Comparable figures regarding implicit pension debts are not available, as a couple of definitions exists. Hopefully, a unified approach to the assessment of implicit pension debt and to the treatment of pension schemes in macroeconomic statistics in general, which is being prepared by a working group of actuaries established by the IMF statistics department, will spur research into this field. The first larger and internationally comparable study has been written by Holzmann et al. (2004). They counted the implicit pension debts of 35 low- and middle-income countries.

${ }^{13}$ Also, a summer 2004 downgrade of the Italian debt indicates that rating agencies can, if still imperfectly, signal that a specific country's fiscal policy is approaching unsustainability.
} 
the Maastricht criteria but was omitted in the SGP. The Commission suggested that the SGP should clarify the "satisfactory pace" of debt reduction, and it even hinted that unfunded pension obligations and contingent liabilities should be taken into account.

While the Commission has proposed certain changes to the SGP (such as "more country-specific circumstances" or "prolonged periods of sluggish growth"), EU financial ministers (Ecofin), at their meeting in September 2004, dismissed the Commission's proposal. ${ }^{14}$ The Ecofin council reiterated that the 3-percent-deficit and the 60-percent-debt criteria are of "paramount importance." It did pledge, however, to take debt sustainability into greater account, including "the future costs of aging."

Thus, while the SGP formally remains in place, the European Union is currently without a binding fiscal rule, and its current expansion to 25 members makes the need for precise fiscal rules more urgent.

\section{Do financial Markets Punish Unsustainable Fiscal Policy?}

Let us now turn our attention to the interplay between fiscal policy and financial markets' assessment of government debt. Moreover, we are interested in fiscal policy within a monetary union, as one country's irresponsible fiscal policy might pose extra costs for others in the union. High public debt in one country could raise union-wide interest rates, either through a crowding-out or risk-premium effect, exerting a negative externality on other members. If this in fact were to happen, there might then be a need for common rules or a special institution which would ensure that all the member states behave responsibly in fiscal matters.

This idea of a special institution is based on the implicit assumption that financial markets are not able to fully differentiate between countries with high and low public debts within a monetary union. In fact, it is based on the idea that financial markets base their required risk premium on the debt level of the most indebted country. We investigate this assumption below.

As Goldstein and Woglom (1992) and Bayoumi, Goldstein, and Woglom (1995) note, there are generally three approaches to fiscal discipline within monetary unions. The first, as stressed in the 1989 Delors Report calls for strict fiscal rules as a means to constrain national governments. The second approach, proposed by the European Commission (1990a, 1990b), calls for external fiscal rules in the form of multilateral surveillance and peer pressure. The third approach, market-based fiscal discipline, is based on the idea that financial markets are able, willing, and informed enough to be able to credit-constrain irresponsible governments.

For this approach to work, there are four additional conditions, namely (i) capital must be able to move freely, (ii) full information must be available to sovereign borrowers, (iii) financial markets must be convinced that there are no implicit and explicit guaranties on government debt and that it will not be monetized, and (iv) the financial system must be strong enough to withstand a default of a large borrower. We believe there is a high probability that the EU's financial market does largely fulfill these conditions. It is, of course, questionable as to how the EU's financial market would withstand the default of France or Germany, but it is probably able enough to cope with the default of any other member state.

\subsection{Survey of Relevant Literature}

There have been several studies that have analyzed the market-based-discipline hypothesis and financial markets' capability to punish/reward fiscal policies. Financial markets may either ignore a government's debt level or charge higher interest rates if a government runs excessive deficits. The relationship between debt and interest rates might be either linear (in which interest rates rise proportionally with the amount of debt) or exponential (in which

\footnotetext{
${ }^{14}$ See "Elements for strengthening, clarifying and better implementation of the SGP," Ecofin com-
} munication, September 2004. 
interest rates rise rapidly relative to debt); the latter we refer to as the non-linear relationship. In the first case, fiscal responsibility rests on the assumption that rising costs of additional debt discourage credit-demanding politicians. In the case of non-linear relationship, credit-demanding politicians might eventually be denied access to additional credit. As we are concerned mostly with the monetary-union framework, the literature on monetary-union fiscal policy is the most relevant to our research.

Some basic findings of recent empirical literature on the market-based-discipline hypothesis are described in Table 2. The second column of the table refers to the countries and the time period under consideration, and the third and fourth columns describe the findings of respective studies' preferred specifications concerning linear and non-linear relationships between interest rates on government debt and relevant GDP/GSP ratio. The fifth column describes whether the respective studies estimated the impact of fiscal rules (when applicable, appropriate fiscal rules have in general been found to decrease the borrowing costs of governments). The sixth column simply states whether the respective study was concerned with market-based discipline within a monetary union or federation. ${ }^{15}$

Some evidence of market-based fiscal discipline was identified in the empirical literature we surveyed. Nevertheless, whether financial markets are able to induce sufficient discipline in governments remains unclear, if not unlikely. There seems to be evidence that financial markets require higher default premiums for countries or states (even within federations and monetary unions) with high debt-to-GDP/GSP ratios. On the other hand, evidence that governments might eventually become credit constrained is rather mixed. Therefore, fiscal discipline then rests on the assumption that politicians, facing increasing borrowing costs, pursue alternative policies in order to avoid further borrowing. We doubt that this assumption is relevant, and to argue that there would be no need for fiscal rules within monetary union would be, by our opinion, rather naive.

\subsection{Empirical Investigation of Market-Based Discipline}

Besides surveying the literature, we tested the hypothesis of market-based fiscal discipline ourselves. We sought an existing monetary union with a sustained history, and for which relevant and accurate data are available. Therefore, we examined data from the United States.

There are, surely, differences between the United States and the European Union with respect to the market-based-discipline hypothesis. First, the United States is a fiscal federation in which the federal budget ensures income-variation smoothening. Although original estimates of the extent of such smoothing in the United States by Sala-i-Martin and Sachs (1992) and by Bayoumi and Masson (1995) were revised by Fatás (1998), it seems reasonable to expect that the EU is less federalized than the United States. Therefore, European economies might be less synchronized than U.S. states which offers some rationale for the imposition of fiscal rules in the EU.

Second, the number of countries involved in the EMU is much lower than the number of states in the American federation. Therefore, financial markets might expect an individual EU country to have greater weight within the EMU, i.e., financial markets might expect a higher probability of bail-out in EMU than in the United States, which renders market-based discipline ineffective, and which might offer an additional rationale for the imposition of some form of fiscal rule.

Third, another feature of federal government in the United States is that there is a certain degree of automatic fiscal smoothening, regardless of individual state involvement. On the other hand, there is no international fiscal redistribution within the European Union, so differences in the business cycle within the EU have a greater impact on the public budget balance than they

\footnotetext{
${ }^{15}$ We believe that federated states offer a very close approximation of monetary unions, and, therefore, that the findings concerned with the behavior of relevant variables within federal nation states should offer clues toward answering questions about the nature and behavior of relevant variables within monetary unions.
} 
would in the United States. Thus, European countries may find useful a fiscal rule that compels individual country's to coordinate their fiscal-policy stances, at least partially.

TABLE 2 Empirical Findings of Recent Literature on Market-Based-Discipline Hypothesis

\begin{tabular}{|c|c|c|c|c|c|}
\hline Paper & $\begin{array}{c}\text { Time period } \\
\text { and jurisdictions }\end{array}$ & $\begin{array}{l}\text { Positive rela- } \\
\text { tion between } \\
\text { interest rate on } \\
\text { government } \\
\text { debt and debt- } \\
\text { to-GDP/GSP } \\
\text { ratio (linear) }\end{array}$ & $\begin{array}{c}\text { Relation } \\
\text { between interest } \\
\text { rate on govern- } \\
\text { ment debt and } \\
\text { debt-to- } \\
\text {-GDP/GSP } \\
\text { squared ratio } \\
\text { (non-linear) }\end{array}$ & $\begin{array}{l}\text { Impact of } \\
\text { fiscal rules }\end{array}$ & $\begin{array}{c}\text { Study concerned } \\
\text { with financial- } \\
\text {-market differen- } \\
\text { tiation among states } \\
\text { in federations or } \\
\text { among countries in } \\
\text { monetary union }\end{array}$ \\
\hline $\begin{array}{l}\text { (Goldstein, } \\
\text { Woglom, 1992) }\end{array}$ & $\begin{array}{c}37 \text { American } \\
\text { states, 1982-1990 }\end{array}$ & Yes & $\begin{array}{c}\text { Negative, } \\
\text { Insignificant }\end{array}$ & Yes & Yes \\
\hline $\begin{array}{l}\text { (Alesina, De } \\
\text { Broeck, Prati, } \\
\text { Tabellini, 1992) }\end{array}$ & $\begin{array}{l}12 \text { OECD } \\
\text { countries, } \\
1974-1989\end{array}$ & $\begin{array}{c}\text { Yes, only for } \\
\text { highly indebted } \\
\text { countries or } \\
\text { countries with } \\
\text { quickly growing } \\
\text { debt-to-GDP } \\
\text { ratio }\end{array}$ & n.a. & n.a. & No \\
\hline $\begin{array}{l}\text { (Bayoumi, } \\
\text { Goldstein, } \\
\text { Woglom, 1995) }\end{array}$ & $\begin{array}{c}38 \text { American } \\
\text { states, 1981-1990 }\end{array}$ & Yes & Positive & Yes & Yes \\
\hline $\begin{array}{l}\text { (Mattina, Delorne, } \\
\text { 1997) }\end{array}$ & $\begin{array}{l}3 \text { Canadian } \\
\text { provinces, } \\
1975-1996\end{array}$ & Yes & Positive & n.a. & Yes \\
\hline $\begin{array}{l}\text { (Alexander, Anker, } \\
\text { 1997) }\end{array}$ & $\begin{array}{l}8 \text { EU countries, } \\
1979-1995\end{array}$ & Yes & n.a. & n.a. & No \\
\hline $\begin{array}{l}\text { (Poterba, Rueben, } \\
\text { 1999) }\end{array}$ & $\begin{array}{c}40 \text { American } \\
\text { states, } \\
1973-1995\end{array}$ & Yes & n.a. & Yes & Yes \\
\hline (Lemmen, 1999) & $\begin{array}{c}\text { States/provinces } \\
\text { within following } \\
\text { countries: } \\
\text { Austria, } \\
\text { 1990-1996 } \\
\text { Canada, } \\
\text { 1992-1997 } \\
\text { Germany, } \\
\text { 1994-1996 }\end{array}$ & $\begin{array}{l}\text { Yes for all } \\
\text { countries }\end{array}$ & $\begin{array}{l}\text { Negative for all } \\
\text { countries }\end{array}$ & $\begin{array}{l}\text { n.a. for Austria } \\
\text { and Germany } \\
\text { Yes for Canada }\end{array}$ & Yes \\
\hline $\begin{array}{l}\text { (Lemmen, } \\
\text { Goodhart, 1999) }\end{array}$ & $\begin{array}{l}13 \text { EU countries, } \\
1987-1996\end{array}$ & Yes & n.a. & n.a. & No \\
\hline $\begin{array}{l}\text { (Copeland, Jones } \\
\text { 2001) }\end{array}$ & $\begin{array}{l}5 \text { EU countries, } \\
\text { 1997-1999 }\end{array}$ & Yes for Italy & n.a. & n.a. & No \\
\hline $\begin{array}{l}\text { (Codogno, Favero, } \\
\text { Missale, 2003) }\end{array}$ & $\begin{array}{c}11 \text { EMU countries, } \\
1995-2002\end{array}$ & $\begin{array}{c}\text { Yes in some } \\
\text { countries } \\
\text { No evidence of } \\
\text { EMU break }\end{array}$ & n.a. & n.a. & Yes \\
\hline (Ardagna, 2004) & $\begin{array}{l}16 \text { OECD } \\
\text { countries, } \\
1960-2002\end{array}$ & Yes & n.a. & n.a. & No \\
\hline $\begin{array}{l}\text { (Bernoth, von } \\
\text { Hagen, } \\
\text { Schuknecht, 2004) }\end{array}$ & $\begin{array}{l}13 \text { EU countries, } \\
1991-2002\end{array}$ & $\begin{array}{l}\text { Yes, lower for } \\
\text { the post-EMU } \\
\text { period }\end{array}$ & $\begin{array}{l}\text { Negative, } \\
\text { pre-EMU } \\
\text { Positive, } \\
\text { post-EMU }\end{array}$ & n.a. & Yes \\
\hline
\end{tabular}




\subsection{Model}

Our hypothesis is that the risk premium required by financial markets is positively correlated with the level of public debt in individual U.S. states. We thus investigate the hypothesis that financial markets are rewarding fiscally responsible U.S. states with increased access to financial resources at lower costs.

However, we would like to isolate the effect of rising public debt levels on the risk premium required by financial markets from other sources of variations, such as the economic cycle, variations in the yields of other investment instruments or special provisions, and the limitations of individual American states with respect to their spending and taxing powers.

We use the following model, which captures the major factors that influence the borrowing costs of U.S. states.

$$
\begin{aligned}
& I N T_{i, t}=\alpha_{i}+\beta_{1} \cdot I N F_{t}+\beta_{2} \cdot G S P_{i, t}+\beta_{3} \cdot U N_{i, t}+\beta_{4} \cdot D E B T_{i, t}+\beta_{5} \cdot T_{R A N F S}+{ }_{i, t}+ \\
& +\beta_{6} \cdot S P E_{i, t}+\beta_{7} \cdot R E V_{i, t}+\beta_{8} \cdot S U P_{i, t}+\beta_{9} \cdot F E D_{t}+\varepsilon_{i, t}
\end{aligned}
$$

In the equation, we estimate coefficients for two different dependent variables. Our first dependent variable, $\operatorname{INT}(1)_{i, t}$, in the ideal case would be the interest rate governments of U.S. states would have to pay on their debt. However, as Bayoumi, Goldstein, and Woglom (1995), and Poterba and Rueben (1999) have noted, such data are not easily obtainable, and for several reasons. First, there is limited trading in most state bond issues. Second, state bonds differ widely in their call provisions and in other detailed provisions. Third, many state bonds are sold in bundles, making it difficult to estimate the yield to maturity on a single issue.

We deal with this problem in a rather simple way. With data on state expenditures on interest payments and overall state debt, we calculated the ratio of the two. This ratio roughly measures the cost each state (denoted by subscript $i$ ) has to pay on each dollar of debt in a given year (denoted by subscript $t$ ).

Our second dependent variable, INT(2) $)_{i, t}$, comes from the Chubb Relative Value Study. ${ }^{16}$ The Chubb Corporation, a U.S. insurance company based in New Jersey, has since 1973 conducted a semi-annual survey among municipal bond traders who are asked to give the yield on 5-, 10-, and 20-year maturity general obligation bonds for 39 American states relative to New Jersey. Data from this survey helps to overcome the problem of the direct comparability of yields on the general obligation bonds of different states since they refer to a hypothetical bond, and therefore differences in yields should reflect the different position and credit-worthiness of individual American states, not the special provisions concerning their bonds. Since the survey is conducted semi-annually, we average the data for each year to comply with the rest of our data set, which comprises annual data.

Some important differences between our two dependent variables are worth mentioning. Our first dependent variable, interest payments over debt ratio is rather a measure of past decisions, past development of borrowing, and reflects the fact that government revenues fall behind expenditures. Data from the Chubb survey, on the other hand, captures the credit-worthiness of each state government as a borrower, market valuations of state willingness and ability to raise revenues in order to repay debt, and market valuations of state ability to cope with unpredictable events.

Our set of independent variables includes: a state-specific intercept, $\alpha_{i}$; the nation-wide change of the consumer price index (to capture a notion of expectations based on past experience, inflation is lagged by one year in our specification), $I N F_{t}$; the percentage growth of product of a given state in a given year, $G S P_{i, t}$; the unemployment rate in a given state and year, $U N_{i, t}$, public debt expressed as a percentage of GSP in a given state and year, $D E B T_{i, t}$; the amount of transfers from the federal government to the given state expressed as a percentage

\footnotetext{
${ }^{16}$ The same data were used by Goldstein and Woglom (1992), Bayoumi, Goldstein, and Woglom (1995) and Poterba and Rueben (1999).
} 
of its expenditure in a given year, $T R A N S F_{i, t}$, three dummy variables, which take on value of 1 if a given state in a given year had a special provision limiting expenditures, $S P E_{i, t}$, revenues, $R E V_{i, t}$, or enact new taxes, $S U P_{i, t}$; and the yield on federal ten-year constant-maturity securities in a given year, $F E D_{t}$.

The sign and value of $\beta_{4}$ determines whether the market-discipline hypothesis is valid or not. In the event that $\beta_{4}=0$, financial markets are not able to discriminate between fiscally prudent and irresponsible governments. Conversely, when $\beta_{4}>0$, financial markets do punish those government that borrow heavily.

\subsection{Results}

We were able to obtain data for all 50 American states from 1978 through 2000 for our first dependent variable, and data for 39 American states from 1991 through 2000 for our second dependent variable. The main data source was the Statistical Abstract of the United States, published by the U.S. Bureau of Census; data about interest rates on federal securities came from the Federal Reserve Board; and information about spending and taxing limits come from Poterba and Rueben (1999) and ACIR (1995).

All the data are in a logarithmic form (except for dummy variables) so that the estimated coefficients can be interpreted as elasticities. We estimated the relevant coefficients using panel-data procedure and report the results in the Table 3.

Inflation, captured by the coefficient $\beta_{1}$, has a non-monotical influence on government bond yields - notice the difference between the coefficient for inflation for the first and second dependent variable. Our first dependent variable, as already mentioned, is rather a past-oriented concept, and therefore the negative coefficient captures an inflation-tax phenomenon whereby expected inflation increases nominal yields, as financial markets require stable real yields. On the other hand, positive coefficient estimates, based on financial-market data, a future-oriented concept, capture the attempt of lenders to secure their real interest rates. In other words, unexpected inflation erases a part of the past obligations, i.e., it is an implicit tax.

As one might expect, $\beta_{2}$ has a positive and $\beta_{3}$ a negative sign since favorable economic development lowers the borrowing costs of governments.

The sign and value of $\beta_{4}$ determines whether the market-discipline hypothesis is valid or not. If $\beta_{4}$ were non-significant, financial markets would not be able to discriminate between fiscally prudent and irresponsible governments. But $\beta_{4}$ is positive, which means that we cannot reject the hypothesis. The model yields the same magnitude of estimated variable for the debt-to-GSP ratio, and basically the same significance level across the specifications. Nevertheless, the coefficient $\beta_{4}$ is relatively low compared to other coefficients of significant variables.

A few other things ought to be mentioned. First, notice in Table 3 the difference between the coefficient for inflation for the first and second dependent variable. We interpret this given that our first dependent variable, as previously mentioned, is rather a past-oriented concept, and therefore the negative coefficient captures inflation tax. On the other hand, positive coefficient estimates, based on financial-market data, a future-oriented concept, captures the attempt of lenders to secure their real interest rates.

Second, notice that for our first dependent variable, an estimated coefficient for a dummy variable describing the limitation of government to enact new taxes, is highly insignificant (therefore, we excluded it in the second column, and, in the third column, we excluded all remaining insignificant variables). This is consistent with the positive coefficient for revenue limitations, which yield higher debt-servicing costs simply because governments, instead of being able to raise relevant revenues, resort to the debt financing of their activities.

This brings us to the third point. Notice that the dummy variable for revenue limitations is insignificant in the model with market-survey data. This is consistent with the idea that financial markets are not concerned with governments' overall limitations on revenue, but that they are concerned with their ability to raise additional revenue through new taxes. 
TABLE 3 Test of the Market-Discipline Hypothesis

\begin{tabular}{|l|c|c|c|c|c|c|}
\hline \multirow{2}{*}{ Coefficient } & \multicolumn{3}{|c|}{ First dependent variable, INT(1) $)_{i, t}$} & \multicolumn{3}{c|}{ Second dependent variable, } \\
\hline$\beta_{1}$ (inflation) & -0.136 & -0.137 & -0.133 & 0.029 & 0.029 & \\
& $(-9.40)$ & $(-9.43)$ & $(-9.29)$ & $(1.47)$ & $(1.48)$ & - \\
$\beta_{2}$ (GSP growth) & -0.214 & -0.214 & & -0.504 & -0.504 & -0.579 \\
& $(-1.12)$ & $(-1.20)$ & - & $(-2.30)$ & $(-2.30)$ & $(-2.70)$ \\
$\beta_{3}$ (unemployment) & 0.117 & 0.116 & 0.126 & 0.087 & 0.087 & 0.101 \\
& $(4.77)$ & $(4.75)$ & $(5.52)$ & $(3.49)$ & $(3.59)$ & $(4.78)$ \\
$\beta_{4}$ (debt-to-GSP ratio) & 0.076 & 0.076 & 0.076 & 0.080 & 0.080 & 0.078 \\
& $(2.37)$ & $(2.36)$ & $(2.43)$ & $(2.35)$ & $(2.34)$ & $(2.17)$ \\
$\beta_{5}$ (transfers from federal) & -0.351 & -0.348 & -0.368 & -0.025 & -0.025 & - \\
& $(-6.41)$ & $(-6.32)$ & $(-7.16)$ & $(-0.49)$ & $(-0.49)$ & \\
$\beta_{6}$ (dummy for spending & -0.050 & -0.047 & & -0.030 & -0.030 & - \\
limit) & $(-1.82)$ & $(-1.83)$ & - & $(-1.61)$ & $(-1.62)$ & \\
$\beta_{7}$ (dummy for revenue limit) & 0.043 & 0.047 & & 0.001 & & \\
$\beta_{8}$ (dummy for new tax & $(1.23)$ & $(1.47)$ & - & $(0.03)$ & - & - \\
limitations) & 0.016 & & & 0.041 & 0.042 & - \\
$\beta_{9}$ (interest on federal & $(0.45)$ & - & - & $(1.87)$ & $(2.13)$ & \\
securities) & 0.179 & 0.179 & 0.164 & 0.047 & 0.047 & 0.100 \\
$R^{2}$ & $(5.36)$ & $(5.37)$ & $(5.60)$ & $(1.19)$ & $(1.19)$ & $(2.53)$ \\
\hline Number of observations & 1100 & 1100 & 1100 & 390 & 390 & 390 \\
\hline
\end{tabular}

Notes: Data span from 1978 through 2000 for first dependent variable and from 1991 through 2000 for second dependent variable. Values of heteroskedastic-consistent t-statistics are in parentheses. Both models estimated by fixed effect procedure (unambiguously suggested for INT(1) variable by Hausman test and not yielding significantly different results for INT(2) variable).

And lastly, notice the difference in significance in the coefficient for transfers from the federal government. Significant estimates for our first dependent variable reveal that higher federal transfers allow state governments to rely less on debt financing; nevertheless, this is not taken in account by financial markets, which are concerned primarily with governments' ability to find additional funds for debt repayment.

\subsection{Correlation of Debt Ratio with State Ratings}

There is another way how to test the hypothesis whether markets are or are not able to distinguish responsible from irresponsible governments. We collected the credit ratings of individual American states from 1995 through 2002 as conducted by major rating agencies and calculated its correlation with a fiscal variable of our concern - the debt-to-GSP ratio of individual states. $^{17}$

Clearly, there is a relation between the rating of an individual state and its debt-to-GSP ratio. This is consistent with Standard and Poor's (2004), who state that debt-to-GSP ratio of

\footnotetext{
${ }^{17}$ Since ratings are reported in letterform, we translated them into numerical values. A higher number means a lower rating. We did not perform regression analysis since credit ratings take on seven different values (nine for Moody's) and change discretely.
} 
individual states is among the criteria which determine the ratings for each state. Since credit ratings in many cases serve as the primary source of information many lenders acquire about their perspective investment, it is clear that debt-to-GSP ratio, through rating agencies, is positively correlated with the borrowing costs any state must face.

TABLE 4 Correlation of State Debt (expressed as \% of GSP) with State Rating

\begin{tabular}{|l|c|c|c|c|c|c|c|c|}
\hline & $\mathbf{1 9 9 5}$ & $\mathbf{1 9 9 6}$ & $\mathbf{1 9 9 7}$ & $\mathbf{1 9 9 8}$ & $\mathbf{1 9 9 9}$ & $\mathbf{2 0 0 0}$ & $\mathbf{2 0 0 1}$ & $\mathbf{2 0 0 2}$ \\
\hline Standard \& Poor's & 0.23 & 0.31 & 0.30 & 0.37 & 0.39 & 0.37 & 0.30 & 0.17 \\
Moody's & 0.39 & 0.44 & 0.44 & 0.45 & 0.34 & 0.32 & 0.24 & 0.22 \\
Fitch & 0.36 & 0.39 & 0.39 & 0.40 & 0.32 & 0.31 & 0.18 & 0.19 \\
\hline
\end{tabular}

Notes: The average number of rated states was 42 by Standard \& Poor's, 40 by Moody's, and 33 by Fitch. The correlation is a rating with a one-year lagged debt-to-GSP ratio. The test statistics for the hypothesis of independence ranges, depending on the number of rated states, from 0.29 to 0.38 at a 5-percent significance level.

But the correlation has lessened in the past few years. Although we do not have an explanation for such a development, the result is that rating agencies seem to be decreasingly concerned about the debt-to-GSP ratio of American states. On the one hand, this could be the result of U.S.-specific events, which is not relevant for a discussion of fiscal rules at the European level. On the other hand, if the lower correlation reflects a weaker link between debt level and market apprehension, it provides another argument for increasing the role of an institutional fiscal rule - as discussed in detail later on.

\section{Internal and External Externality}

In this place, it is relevant to distinguish between external externality from borrowing and internal externality from borrowing. External externality from borrowing refers to the externality irresponsible government places on other states of monetary union or in a federation through its increasing indebtedness. The literature and our own findings suggest that financial markets are able to internalize this effect and punish irresponsible behavior, at least temporarily.

Internal externality refers to the possible impact that excessive borrowing might pose on future generations in a given country. However, higher debt levels over the past several decades, in spite of the globalization of capital markets and increased financial liberalization, suggests that this sort of externality is not being internalized by financial markets.

In other words, the external externality may be interpreted as a form of interregional redistribution, while internal externality might be considered as a form of intergenerational redistribution. Growing debt levels, i.e., increasing intergenerational redistribution, might offer a reasonable rationale for the imposition of an appropriate fiscal rule that would compel politicians to take in account the interests of future generations.

Another rationale for the imposition of fiscal rules is that financial markets tend to overreact. The series of financial crises that took place over the last two decades offers a clear example. Despite that macroeconomic stabilization might be effected relatively quickly, the confidence of financial markets might take longer to restore. Therefore, fiscal rules might serve as a prevention that ensures that governments limit their borrowing well before their debt reaches critical levels.

There are two additional channels through which the irresponsible behavior of one country might impose extra costs on other countries within a monetary union. The first channel came to be known in the economic literature as the crowding-out effect. The high debt level of one country might raise, ceteris paribus, interest rates for other countries. Recent findings of Laubach (2003) and the findings and survey of Mühleisen and Towe (2004) suggest that some 
crowding-out takes place. The second channel- the contagion effect- refers to the default of one country within a monetary union or federation which might temporarily rise interest rates for others, i.e., contagion occurs. However, as Eichengreen and Wyplosz (1998) show, a contagion effect by itself does not offer a sufficient rationale for the imposition of fiscal rules.

We can summarize the hitherto discussion as follows: (i) financial markets are able to distinguish between fiscally responsible and irresponsible governments; (ii) nevertheless, we doubt that financial markets might solve all the problems associated with fiscal policy, especially as they seem unable to solve the intergenerational redistribution (internal externality) aspect of the fiscal-policy problem; (iii) further, financial markets, when it comes to reaction, usually punish fiscal irresponsibility in a harsh way; and (iv) financial markets seem to reward countries with sound fiscal rules with lower default premiums - thus, fiscal rules lower the costs associated with governmental debt.

\section{Sustainability Council}

As the discussion above illustrates, it is not easy to define a robust, efficient, and incentive-compatible fiscal rule. Indeed, we have seen how the SGP fails many tests that a good fiscal rule must pass. In this chapter, we endeavor to propose a fiscal rule that, according to us, would better suit the EU's needs and that would be more robust vis-à-vis political pressure. ${ }^{18}$

We suggest creating a Fiscal Sustainability Council (FSC), which would better cope with the inherited weaknesses of the SGP. We do not suggest that any institution - whether a SGP or a FSC-would be able to solve the bias of national governments to excessive deficits. We, however, do believe that a properly structured institution may increase the incentives for politicians to run more responsible fiscal policy.

As noted above, one of the main shortcomings of the SGP is its low credibility and its dual character: a country is either in compliance with the SGP or it was threatened by its excessive deficit procedure, despite that the difference in fiscal policy in these two cases might be minimal. This duality made the SGP unlikely to be applied, as it does not provide incentives for good behavior and its penalties are too extreme.

At the same time, we showed that an international-based fiscal rule is more likely to succeed than purely national ones because fiscal policy has an internal-externality aspect, which often leads to excessive deficits. As national politicians find it very difficult to establish a credible and long-standing fiscal-rule framework, we believe that an international institution, namely the EU, offers the best chance for success. If a fiscal rule is embedded in the legislation of a supranational body, such as the EU, it becomes less vulnerable vis-à-vis nationalistic pressure. ${ }^{19}$

As the sad example of the SGP clearly illustrates, credibility and institutional factors are far more important than numerical targets. The SGP failed not because of its "stupidity" but because it was vulnerable to purely political decisions and was not incentive compatible.

Thus, a more fundamental anchoring of fiscal rules, at least in Europe, is needed. We believe that an independent Fiscal Sustainability Council, broadly in line with Wyplosz's proposal (2005), might be the most appropriate candidate. We, however, would complement this in several aspects. First, we stress the forward-looking nature of our fiscal rule. Second, we stress the sustainability of fiscal policies, and, therefore, are concerned with total public debt,

\footnotetext{
${ }^{18}$ As we are primarily concerned with sustainability, it would seem appropriate to define it somehow. Unfortunately, there is no generally agreed on definition of sustainability. Moreover, the literature on this issue is divided into two streams. First, discussing the sustainability of past policies, and second, discussing the future development of fiscal policies and their sustainability, especially in the light of population ageing. If any definition of sustainability should be given, we would tend to support a rather general definition which treats sustainability as a condition in which all current policies can be sustained over long periods of time without urgent need for correction.

${ }^{19}$ The 2003 decision of the Ecofin Council to place the SGP in abeyance does indicate, though, that even international pressure might not suffice always.
} 
which we define as the sum of explicit and implicit public debt. ${ }^{20}$ Third, we believe that the greater the emphasis fiscal rule puts on structural reforms the better. Fourth, we rely on financial markets to punish irresponsible governments and therefore consider the FSC's role to consist primarily of providing reliable, trustworthy, and internationally comparable data and information to agents on financial markets. In other words, we believe that the FSC would ensure that the above-mentioned conditions for market-based discipline would be fulfilled. And fifth, we differ from Wyplosz in the respect that we put much less emphasis on the peer pressure of other states as an effective, coercive force, as we believe that has proved inadequate in the past.

\subsection{Council Setup}

The FSC's first task would be to estimate the amount of implicit debt in each country stemming from obligations future governments will have to deal with as regards demographic ageing. The sum of this implicit debt, and the amount of explicit public debt in each country, is what we call total debt (as \% of GDP), which would be FSC's variable of interest.

A second task would be to decide to what level total debt is to be reduced, along with a decision about the timing of the reduction. The FSC could adjust the targeted level to the latest (i.e., more precise) estimates of demographic indicators. In our example, we have chosen the targeted level of total debt to be 100 percent of GDP, and the time in which the reduction is to be completed at 45 years. While a 100-percent benchmark might seem totally arbitrary, the 45-year time frame has been chosen based on current demographic predictions that imply that impact of population ageing will culminate (from a public-finance point of view) approximately in the year 2050.

The FSC would subsequently calculate the rate of debt reduction solving following equation:

$$
D_{t+1}=D_{t}-\alpha \cdot\left(D_{t}-T\right)
$$

where $D_{t}$ stands for total debt-to-GDP ratio at time $t, T$ stands for the targeted level of total debt to GDP, and $\alpha$ for the rate of debt reduction. The following picture shows the trajectory for three different countries, starting from a level of total debt-to-GDP ratio at 200, 300, and 500 percent of GDP respectively, with $\alpha$ chosen such that in the next 45 years, total debt declines to 100 percent of GDP (for three different countries this implies $\alpha$ to equal $0.07,0.09$, and 0.10 ).

FIGURE 1 Total Debt-Reduction Trajectory

Total debt trajectory

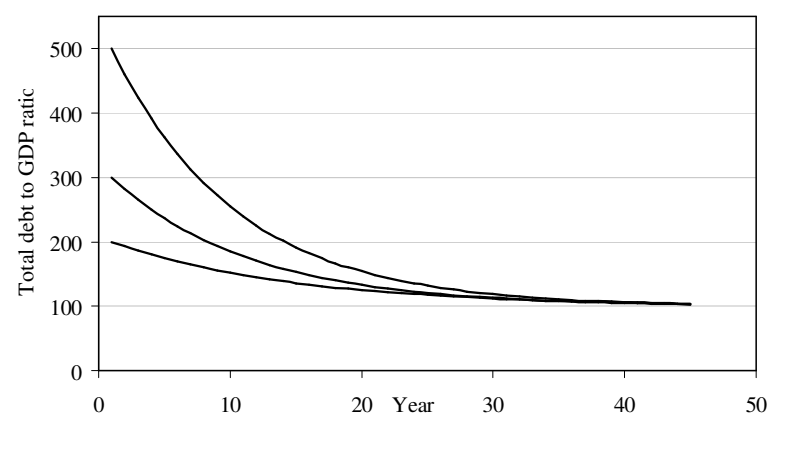

${ }^{20}$ Implicit debt refers to the financial resources any government will need in the future to fulfill its obligations to its citizens. Therefore, what we understand by the term is the discounted sum of future payments into pension, health care, and other social systems. 
The FSC would set a trajectory for each country according to initial level of total debt, which would subsequently serve as the measure of the government's success in reducing the total debt. The initial estimation of level of implicit debt would likely be the most complicated part of the procedure since there is no unified and widely accepted methodology. However, much work and effort has been put into the research connected with this issue, especially since the process of multilateral surveillance under the SGP also made explicit the need for a unified methodology toward the estimation of implicit debt.

After the initial decision is made about time and rate of total debt reduction, and after the necessary search is made for an optimal methodology for assessing implicit debt, the FSC's prime role would be to publish reliable data about how each country is faring with respect to the sustainability of its public finances. Figure 2 helps illustrate the idea.

FIGURE 2 Total and Explicit Debt

Total debt trajectories

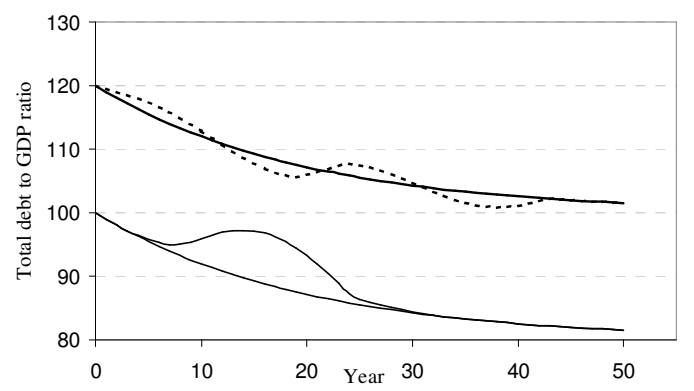

Figure 2 shows a country starting with a public debt-to-GDP ratio of 120 percent, with 100 percent being the targeted debt-to-GDP ratio. The baseline trajectory for total debt reduction set by FSC is the bold, evenly decreasing line starting at 120 percent of GDP. This trajectory is the best solution from the FSC point of view. To maximize the probability that a country follows this path, the FSC would recommend a budgetary balance on an annual basis.

Due to unexpected events, and due to errors in making predictions or due to cyclical movement in business activity, it is more likely that actual movement would follow the trajectory that fluctuates around our baseline scenario. But even this "second-best" development leads to the same result in the long term - see the dashed line.

The lower part of the chart illustrates the advantage of focusing on total debt rather than on explicit debt only. The evenly decreasing lower line is the trajectory of the reduction of the explicit debt based on our best scenario, i.e., our baseline trajectory of total debt. In this exercise, we assume that the implicit debt level remains constant and that the whole debt reduction comes from the explicit debt reduction.

Consider now that due to worsening of demographic changes, implicit debt grows, and that in order to stop this process a government is forced to undertake a structural reform-for example, a reform of the pension system. Such a reform temporarily transfers the implicit part of total debt into the explicit, but in the end ensures the sustainable development of public finances.

This temporary shift in the composition of total debt is illustrated by the hump in the lower-left part of the chart where the explicit debt increases, but the total debt keeps falling, due to a strong elimination of the implicit debt. Since the FSC would not be concerned with the level of explicit debt, a government envisaging a structural reform would not be constrained by the requirement to not increase the explicit debt level. This is what we believe makes our proposal better than the existing SGP: it does not punish governments for measures that ensure the long-term sustainability of fiscal policy but which temporarily increase the level of public debt. 


\subsection{Council inDependence}

The FSC, if it is to work properly, must be independent from regular political-cycle considerations, i.e., it must be shielded from member countries' national governments. Therefore, an appointment system, similar to the one applied to the European Central Bank's governing council, is recommended. We would further recommend that the FSC be chaired by senior economists selected and appointed by the European Parliament.

Importantly, the FSC would not interfere with member countries' routine fiscal- and tax-policy issues. The sole responsibility of the FSC would be to set levels of fiscal deficit for any given year with respect to two factors: (a) a member country's position in the business cycle, and (b) a member country's total indebtedness (including explicit and implicit debt). The FSC would announce the targeted deficits (or surpluses) for each member country well in advance, so that the respective governments could draft their budgets in which they can implement any policy preference they choose. The Council would not define levels of revenues or expenditures, so a government may reach the deficit target with very different tax revenues and expenditures. The policy aspect of fiscal policy would be, thus, maintained. Here, a parallel with central-bank independence is evident.

Long-term fiscal sustainability requires intertemporal budget constraints for the general government to be satisfied:

$$
b(t) \leq \int_{t}^{\infty} e^{-\int_{t}^{v}[r(u)-n(u)] d u}[\tau(v)-g(v)] d v
$$

where $b(t)$ is the ratio of government debt to GDP, $r$ is interest rate, $n$ is the nominal GDP growth, $\tau$ is the total government revenues, and $g$ represents total government expenditures.

However, this seemingly straightforward solution is based on long-term forecasts and is, thus, susceptible to governments' short-term goals. There is one important consideration to be made here. Most European governments rely on the pay-as-you-go (PAYG) principle in financing their social-security systems. However, PAYG pension systems are generally unfunded (or under-funded) due to rapidly aging populations in Europe, though the debt is thus far implicit. However, this implicit debt represents an estimate of costs that will be faced by future taxpayers. It will be either in the form of higher taxes and/or lower pensions, or in the form of debt incurred during a reform.

Any fiscal rule that wants to be forward-looking must thus take into account this implicit debt and must include it in its provisions. We argue that this aspect further reinforces the argument for making fiscal institutions as independent from government as possible, as government would undoubtedly attempt to manipulate the implicit debt estimates.

\subsection{Financial Markets as an Arbiter}

The rules and conditions applied above share one major weakness with other proposed modifications of the SGP, i.e., a weak enforcement mechanism. Generally, it is very difficult to devise a fiscal rule that will be incentive compatible for governments and that will have an embedded enforcement mechanism. As we have shown, the SGP failed largely because of its enforcement mechanism, which left decisions on fiscal-policy sustainability in the hands of politicians.

For this reason, our proposal incorporates financial markets as an indispensable part of the enforcing mechanism. Namely, we suggest that any country that is a euro-zone member or becomes a euro-zone candidate vests with the FSC five tranches of its five-year maturity bonds, each tranche equaling 3 percent of GDP of the respective country. ${ }^{21}$ The FSC would then re-

${ }^{21}$ This echoes a similar proposal that large international banks would issue subordinated debt as a measure of their acceptance and assessment by financial markets. Currently, there are only two countries in the EU that have total debt stock lower than the required $15 \%$ of their GDP: Luxemburg and Estonia. They could 
-issue one of these tranches every year, just to maintain a stable stock of bonds of the respective country.

While doing so, the FSC would interact with financial markets and "guide" them as to whether the respective country's fiscal policy is or is not deemed to be sustainable. Thus, a well-run country would receive a positive report from the FSC and, eventually, would enjoy lower interest rates on its debt. On the other hand, a country with excessive fiscal deficits would be labeled as such by the FSC, and, subsequently, financial markets would assess higher interest rates on its debt.

One advantage of such a solution is that financial markets will always be here and credit-demanding governments will always have to play by market rules. As noted by Berndsen (2001), fiscal rules, no matter how carefully designed, usually erode over time and lose their effectiveness, bringing back the old problem of irresponsible fiscal behavior. Our proposal does not rely on fiscal rule as such. Our proposal calls for the creation of an institution that would be able and willing to supply relevant and reliable information about the fiscal stance of individual countries to financial markets.

Second, our proposal works gradually and is free of the above-mentioned duality that hampered the SGP. A government gets awarded (or punished) by interest rates on its debt a few basic points lower (or higher), and this process takes place regularly, on an annual basis. Thus, a well performing country is motivated to maintain its good performance and a fiscally profligate government is deterred from a further escalation of fiscal deficits by financial markets' regular assessment of its policy.

\section{Conclusion}

In this paper we have demonstrated that fiscal policy has not yet lost its deficit bias. We argued that temporal inconsistency, present in all government actions, demonstrates itself in fiscal policy as strongly as it used to in monetary policy. We thus argued that the fiscal-policy framework should, and could, be changed in a way emulating the separation of monetary policy from regular government intrusion.

We showed that financial markets are indeed able to separate "good" from "bad" fiscal policies and punish the latter by assessing higher borrowing costs. However, the potential spill-over effects of a fiscal crisis in a member country do justify some pan-union fiscal institutional framework. We argued that governmental bias toward deficits might be best contained by vesting deficit decisions with an independent sustainability council.

We also argued that such council should take into account implicit fiscal debt, not only explicit debt. This would better prepare public budgets for a rapid increase in expenditures as baby-boomers head for their retirement and will draw public pensions and use public-health-care programs on an unprecedented scale.

Crucially, we argued that our proposed Fiscal Sustainability Council should be given the right to re-issue a constant fraction of a country debt on a regular basis. This would give the FSC power and opportunity to guide financial markets and to communicate to them which fiscal policies the FSC deems to be sustainable and which not, and, thus, which merit higher interest rates to justify their higher risk of default. This institutional arrangement would rationally link a fiscal institution (the FSC) with financial markets, and would make the fiscal rule less rigid and more market-oriented.

Fiscal policy has become, as we argued above, a threat to long-term sustainable macroeconomic stability in most developed countries. The current fiscal regimes, where the stabilization role of fiscal policy is mostly vested with elected officials, are flawed, as they lead to deficit-biased fiscal policy. It is time to recognize the role of political decision making in fiscal

be either spared the procedure, as their debt level is evidently sustainable, or they can be asked to raise the debt anyway and would be free to save the money raised. 
policy, and to reconsider which aspects of fiscal policy should be institutionalized and more closely wed to financial markets.

Last but not least, our proposal overcomes the problem with endogenous institutions that ensure fiscal responsibility and which presents a serious problem to much of the recent literature on fiscal rules. Any proposal for fiscal rule faces the objection that the author imposes a normative solution, while in fact deficits and rising debt ratios are the result of the will of majority of the citizens in a given country. What we say by our proposal for the FSC is that any nation is free to run any fiscal policy it desires, as long as his behavior has no externalities on other nations. 


\section{References}

ABN AMRO (2003): Desire to retire: The European Pension Problem.

Advisory Council on Intergovernmental Relations (ACIR) (1995): Significant Features of Fiscal Federalism. Vol. 1: Budget Processes and Tax Systems. Washington D.C.

Alesina A, Broeck M de, Prati A, Tabellini G (1992): Default Risk on Government Debt in OECD Countries. Economic Policy, 15:428-463.

Alexander V, Anker P (1997): Fiscal Discipline and the Question of Convergence of National Interest Rates in the European Union. Open Economies Review, 8:335-352.

Ardagna S (2004): Financial Market's Behavior around Episodes of Large Changes in the Fiscal Stance. Wellesley College, 2004.

Barnhill TM jr, Kopits GF (2003): Assessing Fiscal Sustainability Under Uncertainty. IMF working paper, no. 03/79.

Bayoumi T, Masson PR (1995): Fiscal Flows in the United States and Canada: Lessons for Monetary Union in Europe. European Economic Review, 39(2):253-274.

Bayoumi T, Goldstein M, Woglom G (1995): Do Credit Markets Discipline Sovereign Borrowers? Evidence from U.S. States. Journal of Money, Credit, and Banking, 27(4):1046-1059.

Becker .S (1983): A Theory of Competition Among Pressure Groups for Political Influence. The Quarterly Journal of Economics, 98(3):371-400.

Beetsma R, Debrun X (2003): Reconciling Stability and Growth: Smart Pacts and Structural Reforms. CEPR Discussion Paper, no. 3930.

Bernoth K, Hagen J von, Schuknecht L (2004): Sovereign Risk Premia in the European Government Bond Market. ECB working paper, no. 369.

Briotti MG (2004): Fiscal Adjustment between 1991 and 2002: Stylized Facts and Policy Implications. European Central Bank Occasional Paper, no. 9.

Buchanan JM, Wagner RE (1977): Democracy in Deficit: Political Legacy of Lord Keynes. Academic Press, New York.

Buti M, Franco D, Ongena H (1997): Budgetary Policies during Recessions: Retrospective Application of the Stability and Growth Pact to the Post-War Period. European Commission, Economic Papers, no. 121.

Codogno L, Favero C, Missale A (2003): Yield Spreads on EMU Government Bonds. Economic Policy, 37:505-532.

Copeland L, Jones SA (2001): Default Probabilities of European Sovereign Debt: Market-based Estimates. Applied Economics Letters, (8):321-324.

Craig J, Kopits G (1998): Transparency in Government Operations. IMF Occasional Paper, no. 158.

Delors' Report: Report of Economic and Monetary Union in the European Community. Committee for the Study of Economic and Monetary Union, Brussels, June 1989.

Eichengreen B, Wyplosz Ch (1998): The Stability Pact: More than a Minor Nuisance? Economic Policy, 26:67-113.

European Commission (1990a): Economic and Monetary Union: The Economic Rationale and Design of the System. Brussels.

European Commission (1990b): One Money - An Evaluation of the Potential Benefit and Costs of Forming an Economic and Monetary Union. Brussels.

European Commission (2004): Statistical Annex of European Economy; Spring 2004. Brussels. 
Fatás A (1998): Does EMU Need a Fiscal Federation? Economic Policy, 26:163-203.

Goldstein M, Woglom G (1992): Market-based Fiscal Discipline in Monetary Unions: Evidence from the US Municipal Bond Market. In: Canzoneri MB, Grilli V, Masson PR (eds.): Establishing a Central Bank: Issues in Europe and Lessons from the US. Cambridge University Press, 228-269.

Hedbavny P, Schneider O (2003): Fiscal Policy: Too Political? Finance a úvěr-Czech Journal of Economics and Finance, 53(11-12):462-476.

Holzmann R, Palacios P, Zviniene A (2004): Implicit Pension Debt: Issues, Measurement and Scope in International Perspective. The World Bank, Social Protection Discussion Paper Series, no. 0403 .

Kopits G, Symansky S (1998): Fiscal Policy Rules. IMF Occasional Paper, no. 162.

Laubach T (2003): New Evidence on the Interest Rate Effects of Budget Deficits and Debt. Board of Governors of the Federal Reserve System.

Lemmen JJG, Goodhart ChAE (1999): Credit Risk and European Government Bond Markets: A Panel Data Econometric Analysis. Eastern Economic Journal, 25(1):77-107.

Lemmen JJG (1999): Managing Government Risk in Federal States. FMG special paper, no. 116 .

Mattina T, Delorne F (1997): The Impact of Fiscal Policy on the Risk Premium of Government Long-term Debt: Some Canadian Evidence. Department of Finance of Canada, Economic and Fiscal Policy Research Working Paper, no. 1.

Niskanen WA (1968): The Peculiar Economics of Bureaucracy. The American Economic Review, 58(2):293-305.

Noord P van den (2002): Automatic Stabilisers in the 1990s and Beyond. In: Hagen J von, Buti M, Martinez-Mongay C (eds.): The Behaviour of Fiscal Autho-rities: Stabilisation, Growth and Institutions. Palgrave, New York, 130-148.

OECD (2002): OECD Economic Outlook 72. Paris.

Portes R (2003): A Comment. Economic Policy, 37:527-529.

Poterba JM, Rueben K (1999): States Fiscal Institutions and the U.S. Municipal Bond Market. In: Poterba JM, Hagen J von (eds.): Fiscal Institutions and Fiscal Performance. Chicago, University of Chicago Press, 181-207.

Public Finances in EMU 2003. European Economy, no. 3/2003 (September 2003).

Sala-i-Martin X, Sachs J (1992): Fiscal Federalism and Optimum Currency Areas: Evidence for Europe from the Unites States. NBER Working Paper, no. 3855.

Schneider O (1999): Implicit Public Debt of the Czech Social Security System. Center for Social and Economic Research CASE working paper, no. 167, Warsaw.

Wyplosz C (2005): Fiscal Policy: Institutions Versus Rules. National Institute Economic Review, no.191 (January 2005):70-84.

Standard and Poor's (2004): Local and Regional Governments.

Standard and Poor's (2002): Sovereign Credit Ratings: A Primer. April 2002. 